\title{
ANALISIS DAN IMPLEMENTASI E-COMMERCE DENGAN METODE BUSINESS MODEL CANVAS (STUDI KASUS: TOKO JADE BAG)
}

\author{
Aldy Gustavian ${ }^{1)}$, Samsinar ${ }^{2)}$ \\ ${ }^{1}$ Sistem Informasi, Fakultas Teknologi Informasi, Universitas Budi Luhur \\ ${ }^{1,2} \mathrm{Jl}$. Raya Ciledug, Petukangan Utara, Kebayoran Lama, Jakarta Selatan 12260 \\ E-mail : gustavianaldy@gmail.com ${ }^{1)}$, samsinar@budiluhur.ac.id ${ }^{2)}$
}

\begin{abstract}
Abstrak
Jade Bag merupakan sebuah usaha yang menjual tas wanita sejak tahun 2013. Berdasarkan wawancara yang telah dilakukan, diketahui masalah yang terjadi pada toko Jade Bag bahwa proses bisnis yang berjalan saat ini masih kurang efektif karena proses pemesanan barang hanya dilakukan melalui whatsapp serta cara promosi yang dilakukan toko Jade Bag hanya melalui instagram. Tujuan membangun sistem E-Commerce ini adalah konsumen dapat melakukan pemesanan produk tanpa harus menghubungi pemilik melalui whatsapp sehingga memberikan kemudahan kepada konsumen dalam melakukan pemesanan. Dalam melakukan pemecahan masalah tersebut peneliti menggunakan metode Business Model Canvas. Dengan dibuatnya website penjualan berbasis E-Commerce pada toko Jade Bag maka dapat dijadikan sebagai media promosi, mempermudah proses penjualan, serta dapat mempermudah dalam pengolahan data pemesanan dan pencetakan laporan.
\end{abstract}

Kata kunci: E-Commerce, Business Model Canvas, Bahasa Pemrograman PHP

\section{PENDAHULUAN}

Perkembangan teknologi masa kini semakin pesat, hampir segala aspek yang berhubungan dengan kegiatan menggunakan teknologi terutama jual beli. Jade Bag merupakan UKM yang bergerak pada bidang penjualan tas wanita. Proses pemesanan pada Jade Bag hanya menggunakan whatsapp sehingga sering mengakibatkan terjadinya kesalahan, seperti perhitungan pada jumlah pemesanan, pembayaran dan laporan setiap bulan, masalah seperti ini dapat diatasi dengan adanya Website E-Commerce. E-Commerce merupakan sebuah wadah untuk produsen dengan konsumen dalam melakukan transaksi jual beli yang dilakukan secara elektronik melalui jaringan komputer atau internet [1]. E-Commerce yang dimaksud dalam penelitian ini termasuk dalam golongan Business To Customer. Business To Customer (B2C) merupakan bisnis yang melakukan pelayanan atau penjualan barang yang berhubungan langsung dengan konsumen [2].

Tujuan dari penelitian ini adalah menyediakan fasilitas untuk pemesanan barang yang di jual oleh Jade Bag secara online sehingga customer tidak perlu menghubungi melalui whatsapp untuk melakukan pemesanan, dengan adanya website ini diharapkan dapat menjadi media promosi yang lebih efisien, dan menyediakan fasilitas untuk pengelolaan data transaksi pemesanan dan pengevaluasian penjualan melalui laporan dengan informasi yang lebih baik.

Studi literatur adalah mencari referensi teori yang relevan dengan permasalahan yang ditemukan dapat dicari melalui jurnal, buku, artikel atau bahan bacaan lainnya. Studi literatur bisa didapat dari berbagai sumber yaitu jurnal, buku, dokumentasi, internet dan daftar pustaka [3]. Adapun penelitian yang serupa digunakan oleh penulis diambil dari jurnal dan memiliki korelasi yang searah dengan penelitian ini, antara lain:

Pada penelitian yang berjudul "Perancangan Sistem Informasi Penjualan Berbasis E-Commerce Pada Studi Kasus Toko Kun Jakarta”. Penulis membuat website e-commerce, perancangan dan pembuatan ini dimaksudkan untuk memudahkan penjualan dan promosi. Penelitian ini menggunakan metode waterfall karena model waterfall adalah model SDLC yang paling sederhana, model ini hanya cocok untuk pengembangan perangkat lunak dengan spesifikasi yang tidak berubah-ubah. Penulis juga menggunakan Activity Diagram, Use Case Diagram, dan ERD untuk merancang sistem yang diusulkan [4].

Penelitian yang berjudul "Pengembangan Model Bisnis Sandiwara Store Dengan Menggunakan Pendekatan Business Model Canvas”. Sandiwara Store adalah sebuah perusahaan yang bergerak dibidang industry fashion yang menyediakan pakaian yang bertemakan musik atau film. Namun terdapat permasalahan baik internal maupun eksternal pada masa produksi hingga penjualan. Pada penelitian ini penulis menggunakan metode Business Model Canvas dan analisis SWOT untuk mengetahui kekuatan, kelemahan, peluang, dan ancaman yang ada pada Sembilan Blok elemen Sandiwara Store [5]. 


\section{METODE PENELITIAN}

\subsection{Metode Pengumpulan Data}

Pengumpulan data dilakukan untuk memperoleh informasi yang dibutuhkan dalam rangka mencapai tujuan sebuah penelitian. Berikut merupakan teknik pengumpulan data yang digunakan penulis dalam menyusun penelitian ini beserta penjelasannya, antara lain:

a. Wawancara

Pada teknik ini peneliti mencari data dan informasi dengan cara melakukan tanya jawab dengan narasumber.

b. Observasi

Penulis datang ke rumah pemilik Jade Bag untuk mengamati secara langsung bagaimana proses pemesanan yang dilakukan melalui whatsapp sampai proses pengiriman agar data yang diperoleh lengkap.

c. Studi Kepustakaan

Pada teknik ini penulis melakukan studi kepustakaan dari beberapa jurnal yang ada di internet dan jurnal e-proceeding.

\subsection{Metode Analisis dan Perancangan Sistem}

Pada penelitian ini penulis menggunakan Business Model Canvas (BMC) karena dapat menjadi pendekatan yang bisa diimplementasikan dengan mudah oleh organisasi bisnis dalam upaya melakukan evaluasi, perubahan atau pembenahan atau hanya sekedar peninjauan ulang terhadap model bisnis perusahaan sehingga tercipta model bisnis baru yang lebih tepat dan sesuai untuk diaplikasikan oleh perusahaan. BMC digunakan untuk membantuk memetakan usaha, bertindak sebagai panduan dalam melakukan riset pengembangan usaha dan membantu dalam merancang strategi usaha [6].

\section{HASIL DAN PEMBAHASAN}

\subsection{Business Model Canvas}

Business Model Canvas dapat diartikan secara sederhana yaitu alat ukur keakuratan suatu bentuk usaha yang sedang dijalani atau akan dijalani [6]. Melalui Business Model Canvas toko Jade Bag akan melihat bisnis secara garis besar namun setiap elemen yang terkait dengan bisnis akan terlihat lengkap dan rinci.

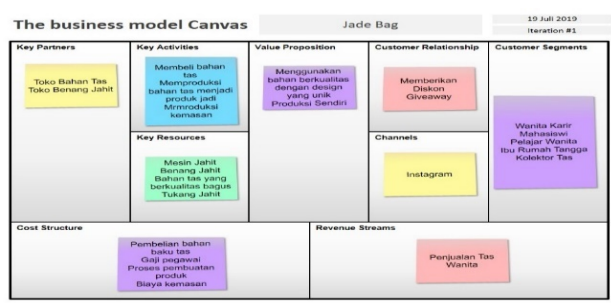

Gambar 1. Business Model Canvas
Berikut yang terlihat pada gambar 1 adalah analisis pembahasan berdasarkan hasil penelitian yang sudah dilakukan

1. Value Proposition

Value Proposition adalah alasan mengapa customer memilih kita dibandingkan yang lain. Keunggulan pada Jade Bag adalah produksi sendiri dan menggunakan bahan yang berkualitas.

2. Customer Segments

Customer Segments adalah pelayanan dari satu atau beberapa segmen customer, kekuatan pada elemen ini adalah Jade Bag sudah memiliki target dan segmentasi yang jelas, yaitu wanita dan kolektor tas. Dalam hal menjada loyalitas customer agar tingkat perpindahannya rendah, pemilik memberikan diskon khusus bagi customer setianya.

3. Revenue Streams

Revenue Stream's adalah arus pendapatan yang dihasilkan oleh perusahaan. Kelemahan dalam elemen ini adalah arus pendapatan hanya bersumber dari satu jenis produk saja yaitu penjualan tas wanita.

4. Key Activities

Key Activities adalah aktivitas utama yang dilakukan oleh perusahaan, dalam elemen ini faktor kekuatan ditunjukkan dari membeli bahan tas hingga memproduksi bahan tas menjadi produk jadi.

5. Key Resource

Key Resources adalah sumber daya utama yang merupakan aset yang dimiliki untuk penawaran terhadap semua elemen. Kekuatan pada elemen ini adalah mesin jahit, benang jahit dan bahan yang digunakan merupakan bahan yang berkualitas bagus, kelemahan dari Jade Bag merupakan produsen tas wanita yang sangat mudah ditiru oleh kompetitor.

6. Customer Relationship

Customer Relationship adalah hubungan perusahaan dengan customer. Berdasarkan hasil yang didapatkan dari wawancara diketahui bahwa cara yang dilakukan Jade Bag dalam menjaga hubungan dengan customer yaitu pemilik Jade Bag memiliki hubungan baik dengan customer, dikatakan baik karena pemilik sering mengadakan giveaway dan diskon. Hal ini dilakukan untuk menjaga loyalitas customer serta agar customer melakukan repeat order.

7. Channels

Channels adalah proses distribusi ke customer melalui komunikasi, distribusi dan penjualan, faktor kelemahan berada pada Jade Bag adalah promosi hanya melaui instagram.

8. Key Partnership

Key Partnership adalah kemitraan utama bagi perusahaan untuk memasok bahan baku. Berdasarkan hasil dari wawancara yang telah dilakukan diketahui faktor kekuatan dalam elemen ini ditunjukkan dari kemampuan Jade Bag dalam 
bekerjasama dengan mitra dan menciptakan hubungan yang baik dengan pemasok. Pemasok tersebut yaitu toko bahan tas.

\section{Cost Structure}

Cost Structure adalah struktur biaya pada perusahaan. Untuk biaya yang dikeluarkan oleh Jade Bag untuk menjalankan proses bisnisnya adalah bahan baku tas, gaji pegawai, proses pembuatan produk, dan biaya kemasan.

\subsection{Proses Bisnis Sistem Usulan}

Proses bisnis yang penulis susun menggunakan activity diagram. Activity Diagram adalah proses penggambaran dan urutan dari aktivitas dalam suatu proses secara keseluruhan [7].

Sistem penjualan yang sedang berjalan saat ini menjadi sebuah ide bagi peneliti untuk mengusulkan sebuah proses bisnis yang lebih efektif dan efisien. Berikut proses bisnis sistem usulan:

a. Proses Pemesanan Produk

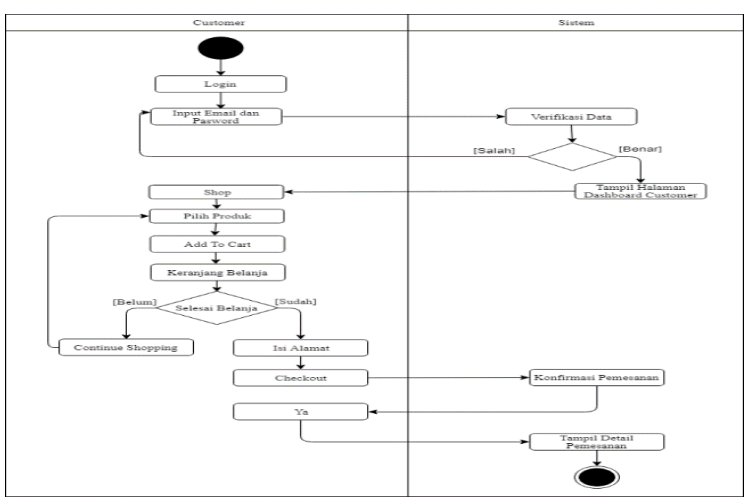

Gambar 2. Proses Pemesanan Produk

Yang terlihat pada gambar 2 ada satu (1) actor yaitu customer dan sistem. Customer yang ingin memesan produk harus login sebelum melakukan transaksi. Customer memilih produk lalu menentukan warna dan jumlah produk yang ingin dibeli setelah itu customer mengisi alamat pengiriman dan konfirmasi pemesanan kemudian sistem akan menampilkan detail pemesanan.

b. Konfirmasi Pemesanan

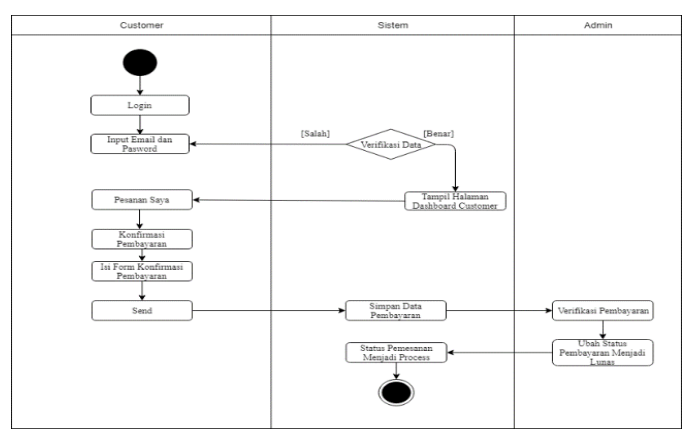

Gambar 3. Proses Konfirmasi Pembayaran
Yang terlihat pada gambar 3 ada tiga (3) actor yaitu customer, sistem dan admin. Customer yang sudah melakukan pembayaran dapat mengkonfirmasi pembayaran melalui website dengan cara login ke website. Pada menu dashboard customer klik tombol pesanan saya lalu klik tombol konfirmasi pembayaran, jika sudah akan muncul form konfirmasi pembayaran. Jika semua form telah di isi lalu klik tombol send kemudian admin akan melakukan verifikasi data pembayaran, jika data pembayaran valid admin merubah status pembayaran menjadi lunas dan secara otomatis sistem akan merubah status pemesanan menjadi process.

c. Pengiriman

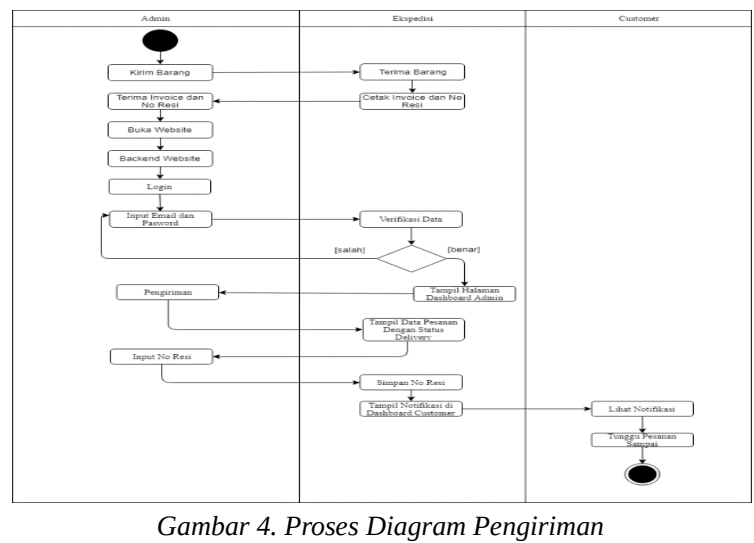

Yang terlihat pada gambar 4 ada tiga (3) actor yaitu admin, ekspedisi dan customer. Admin melakukan pengiriman menggunakan jasa ekspedisi, ketika barang sudah dikirim dan admin menerima no resi maka admin input no resi di website. Admin membuka menu pengiriman maka akan muncul data pemesanan dengan status delivery. Kemudian admin klik tombol input resi lalu masukan nomor resi dan klik simpan maka sistem akan menampilkan notifikasi bahwa barang sudah dikirim di menu dashboard customer.

\subsection{Pemodelan Sistem Usulan}

Use Case Diagram merupakan interaksi antara satu atau lebih aktor dengan sistem informasi yang akan dibuat [7].

Untuk memodelkan sistem usulan, peneliti menggunakan Use Case Diagram sebagai berikut :

a. Use Case Diagram Master

Yang terlihat pada gambar 5 merupakan Use Case Diagram Master. Terdiri dari 1 actor yaitu admin. Admin dapat menginput kategori produk, produk, kategori blog, dan blog. 


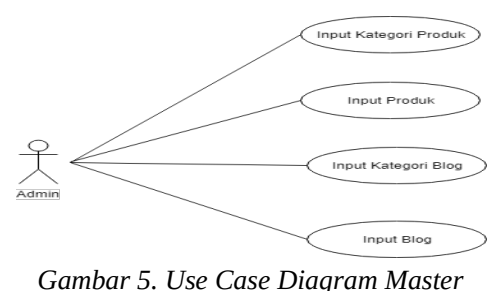

b. Use Case Diagram Transaksi Customer

Yang terlihat pada gambar 6 merupakan Use Case Diagram Transaksi Customer. Terdiri dari 1 actor yaitu customer. Customer dapat membuat pesanan, melihat keranjang belanjam checkout pesanan, konfirmasi pembayaran, cek detail pesanan dan melakukan retur.

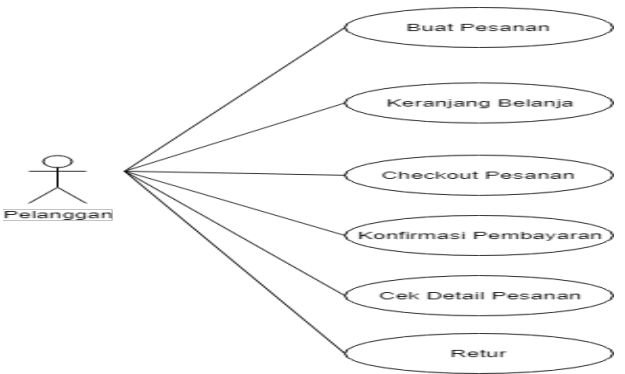

Gambar 6. Use Case Diagram Transaksi Customer

c. Use Case Diagram Transaksi Admin

Yang terlihat pada gambar 7 merupakan Use Case Diagram Transaksi Admin. Terdiri dari 1 actor yaitu admin. Admin dapat mengganti status pemesanan, ganti status pembayaran dan melakukan pengiriman.

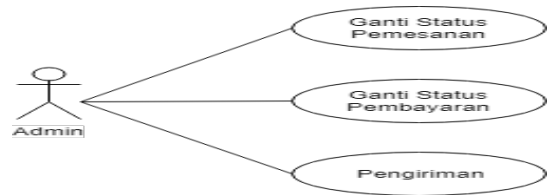

Gambar 7. Use Case Diagram Transaksi Admin

\section{d. Use Case Diagram Laporan}

Yang terlihat pada gambar 8 merupakan Use Case Diagram Laporan. Terdiri dari 2 actor yaitu admin dan pemilik. Admin dapat menginput mencetak laporan pengiriman, pembayaran, pemsanan, retur, produk terlaris dan laporan stok produk kemudian menyerahkan laporan kepada pemilik.

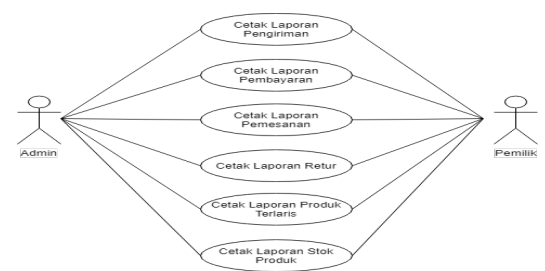

Gambar 8. Use Case Diagram Laporan

\subsection{Pemodelan Data}

Class Diagram merupakan diagram yang menunjukan class-class yang ada di sistem dan hubungannya secara logic [7].

Yang terlihat pada gambar 9 penulis memodelkan data secara konseptual menggunakan class diagram sebagai berikut:

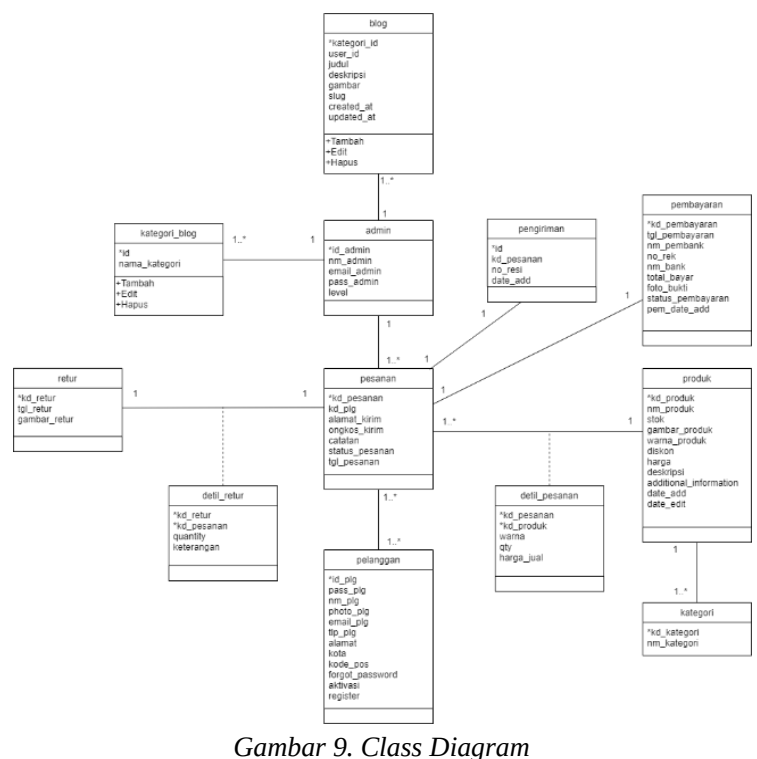

\subsection{Desain Graphical User Interface}

a. Tampilan Layar

Berikut adalah tampilan layar dari sistem usulan toko Jade Bag :

1) Tampilan Frontend Form Registrasi Customer

Pada gambar 10 merupakan tampilan form registrasi customer yang harus di isi customer untuk membeli produk.
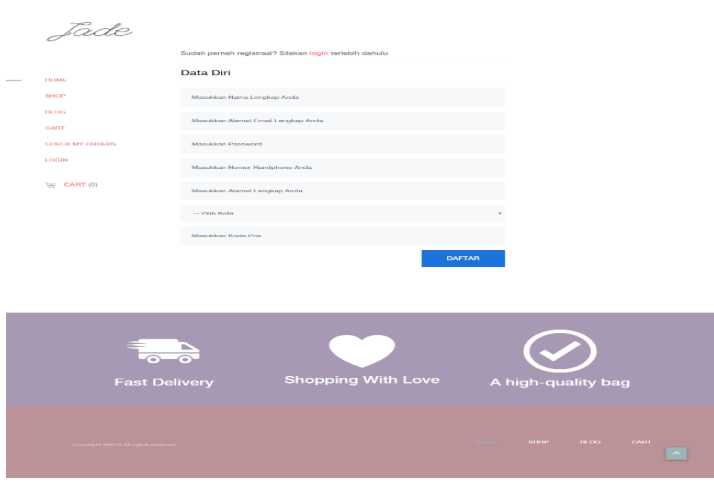

Gambar 10. Tampilan Frontend Form Registrasi Customer

2) Tampilan Frontend Produk

Pada gambar 11 merupakan tampilan produk, pada menu ini customer dapat melihat semua produk. 


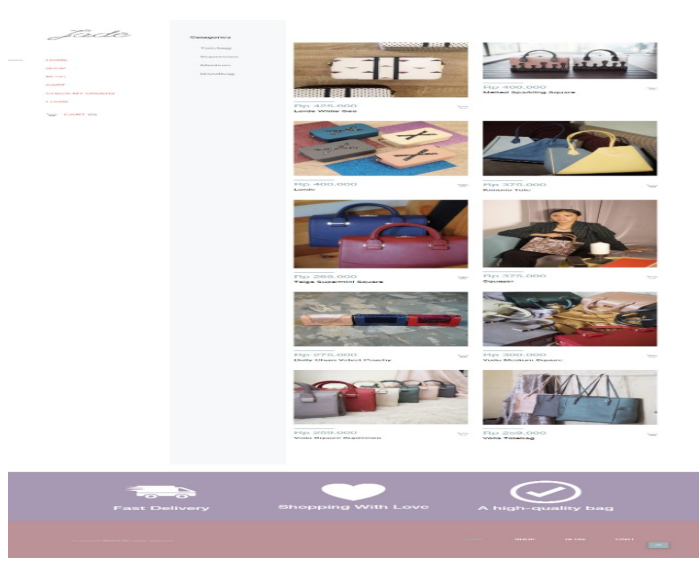

Gambar 11. Tampilan Frontend Produk

3) Tampilan Frontend Detail Produk

Pada gambar 12 merupakan tampilan detail produk, pada menu ini customer dapat melihat jumlah stok, warna yang tersedia sekaligus bisa menambah produk ke keranjang belanja.
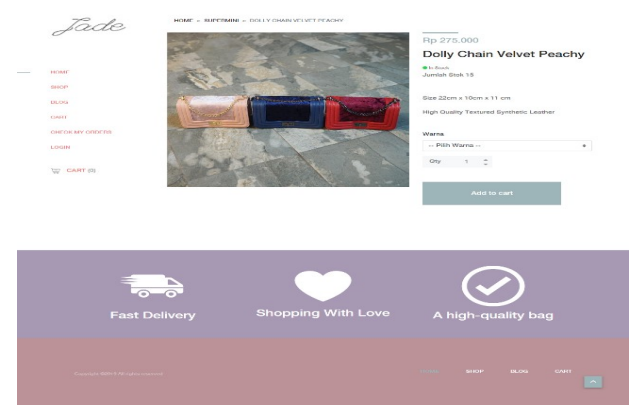

Gambar 12. Tampilan Frontend Detail Produk

4) Tampilan Frontend Keranjang Belanja

Pada gambar 13 merupakan tampilan keranjang belanja, pada menu ini customer dapat menambah, mengurangi, menghapus produk yang akan dibeli.
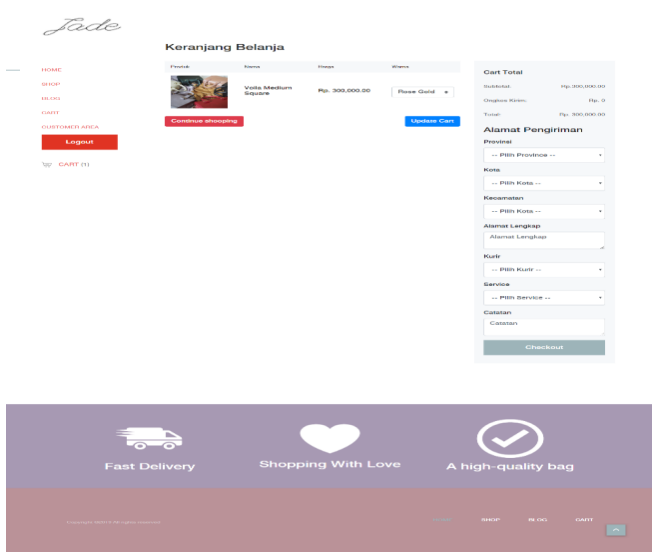

Gambar 13. Tampilan Frontend Keranjang Belanja
5) Tampilan Frontend Dashboard Customer

Pada gambar 14 merupakan tampilan dashboard customer, pada menu ini customer dapat melihat jumlah pesanan, profil, retur barang.
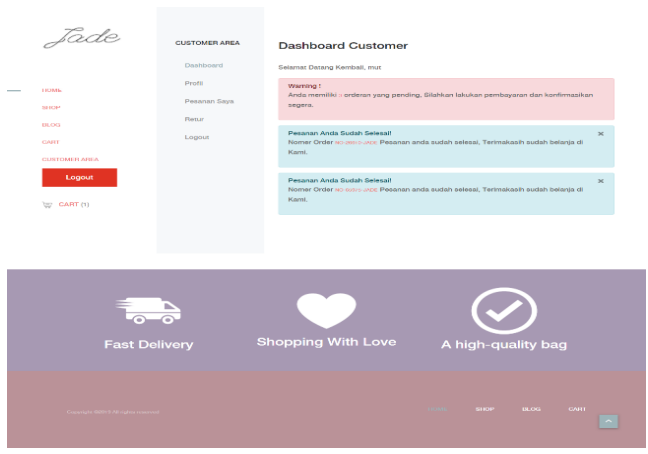

Gambar 14. Tampilan Frontend Dashboard Customer

6) Tampilan Frontend Daftar Pemesanan

Pada gambar 15 merupakan tampilan data pemesanan, pada menu ini menampilkan semua data pemesanan yang dilakukan oleh customer.
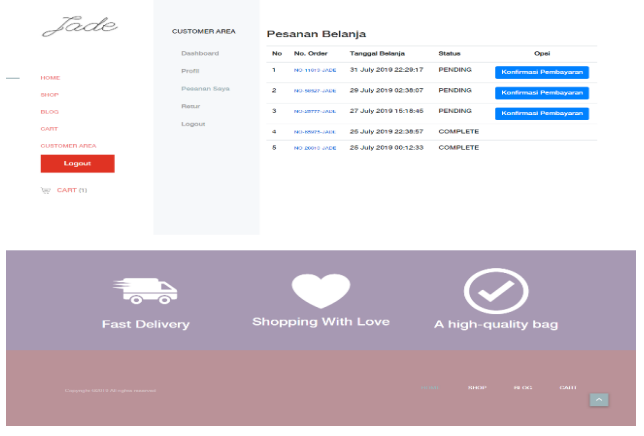

Gambar 15. Tampilan Frontend Daftar Pemesanan

7) Tampilan Frontend Form Konfirmasi Pembayaran

Pada gambar 16 merupakan tampilan form konfirmasi pembayaran, customer harus mengisi form ini untuk mengkonfirmasi pembayaran yang sudah dilakukan

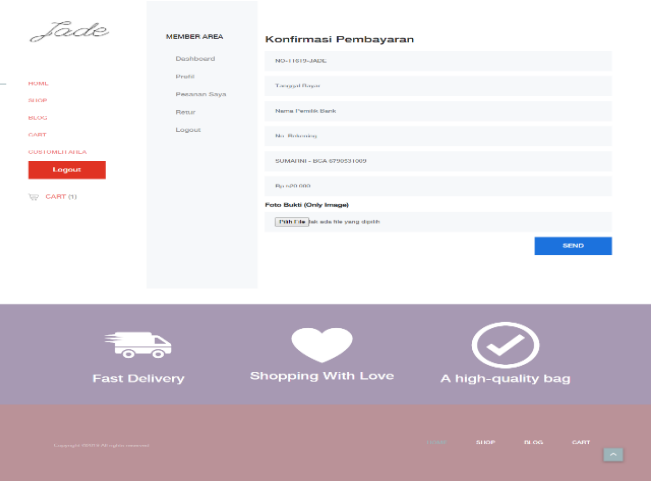

Gambar 16. Tampilan Frontend Konfirmasi Pembayaran 
8) Tampilan Backend Data Pemesanan

Pada gambar 17 merupakan tampilan data pemesanan, pada menu ini admin dapat melihat seluruh data pemesanan dan bisa mengganti status pemesanan.
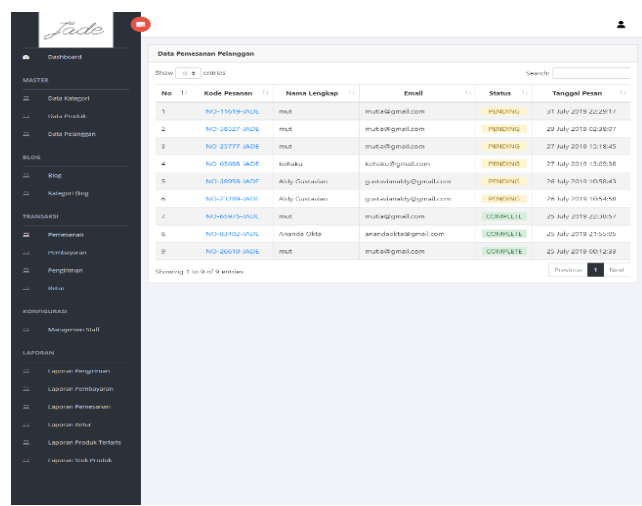

Gambar 17. Tampilan Backend Data Pemesanan

9) Tampilan Backend Data Pembayaran

Pada gambar 18 merupakan tampilan data pembayaran, pada menu ini admin dapat melihat data pemesanan yang sudah dibayar dan mengganti status pembayaran.
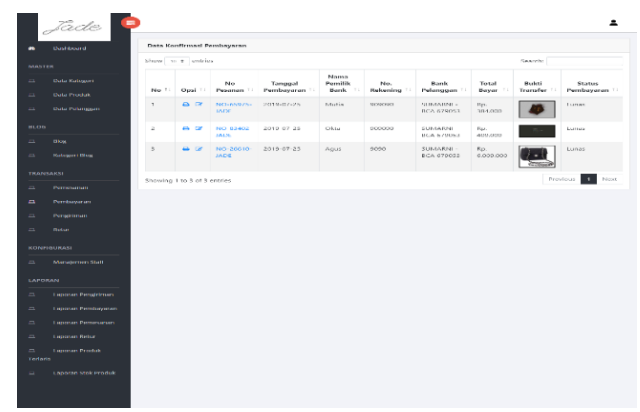

Gambar 18. Tampilan Backend Data Pembayaran

10)Tampilan Backend Data Pengiriman

Pada gambar 19 merupakan tampilan data pengiriman, pada menu ini admin mengisi nomor resi.
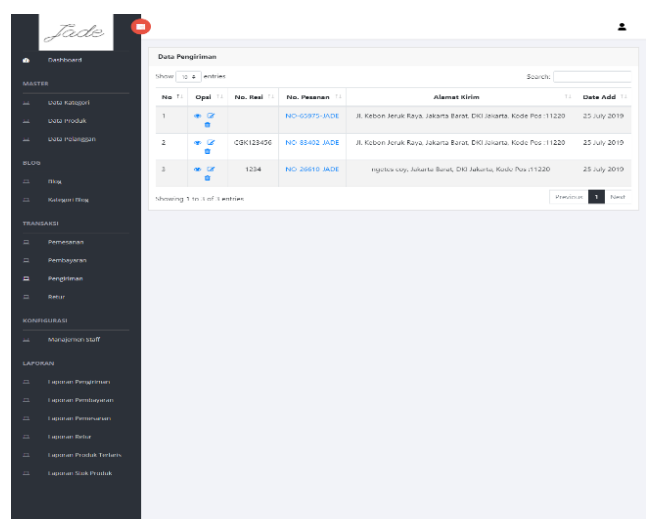

Gambar 19. Tampilan Backend Data Pengiriman
11) Tampilan Keluaran Laporan Pemesanan

Pada gambar 20 merupakan tampilan keluaran laporan pemesanan yang menampilkan data pemesanan yang sudah selesai

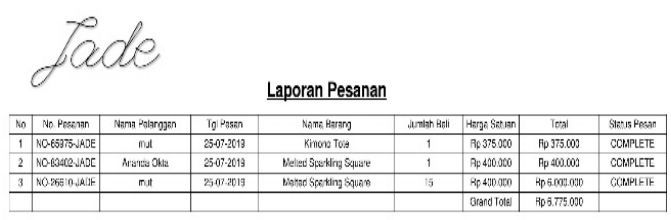

Gambar 20. Tampilan Keluaran Laporan Pemesanan

12)Tampilan Keluaran Laporan Pembayaran Pada gambar 21 merupakan tampilan keluaran laporan pembayaran dengan status sudah dibayar.

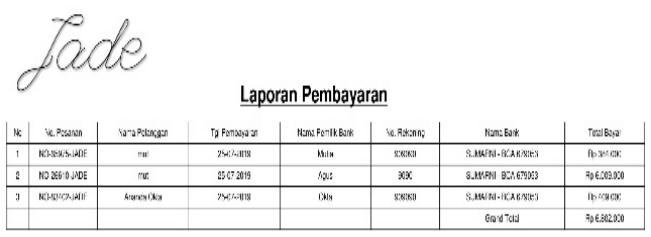

Gambar 21. Tampilan Keluaran Laporan Pembayaran

13)Tampilan Keluaran Laporan Pengiriman

Pada gambar 22 merupakan tampilan laporan pengiriman, pada laporan ini menampilan produk yang sudah dikirim.

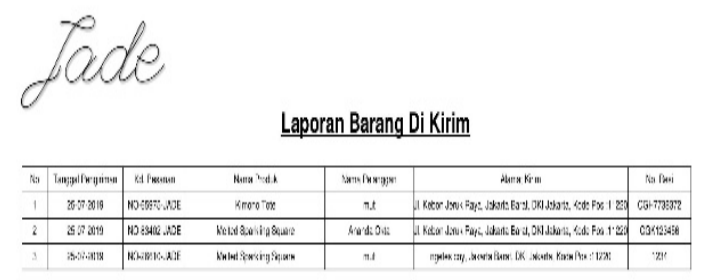

Gambar 22. Tampilan Keluaran Laporan Pengiriman

\subsection{System Sequence Diagram}

System Sequence Diagram (SSD) adalah diagram yang menggambarkan sebuah proses interface yang ada pada sebuah sistem [8].

Berikut proses sistem usulan menggunakan SS :

a. System Sequence Diagram Buat Pesanan 
Pada gambar 23 terlihat proses aliran informasi input dan output buat pesanan yang dilakukan oleh customer.

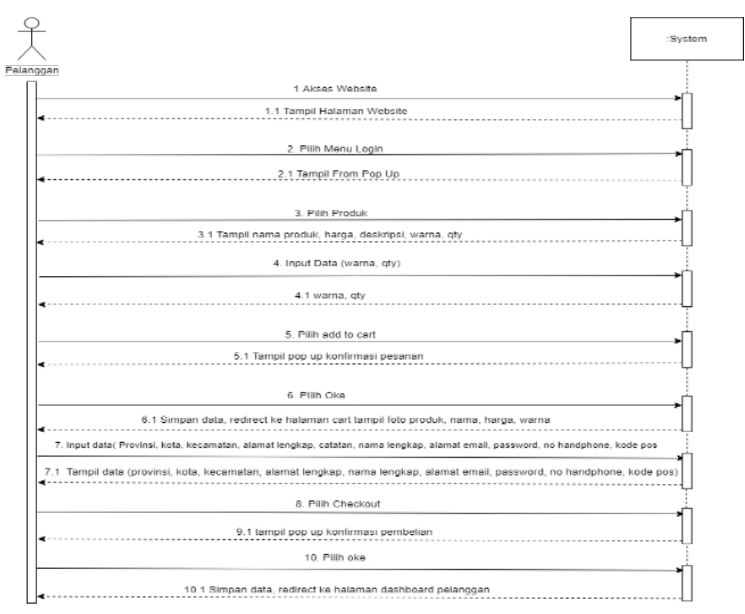

Gambar 23. System Sequence Diagram Buat Pesanan

b. Konfirmasi Pembayaran

Pada gambar 24 terlihat proses aliran informasi input dan output konfirmasi pembayaran yang dilakukan oleh customer.

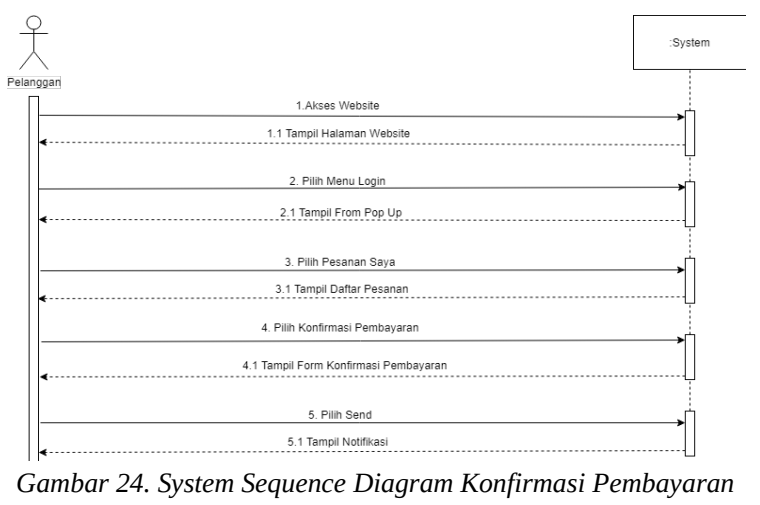

c. Laporan Pemesanan

Pada gambar 25 terlihat proses aliran informasi input dan output laporan pemesanan yang dilakukan oleh admin.

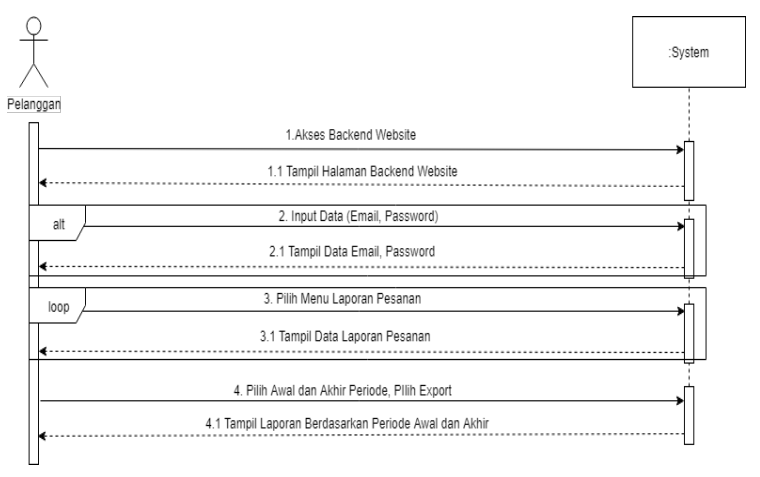

Gambar 25. System Sequence Diagram Laporan Pemesanan

\section{KESIMPULAN}

Rancangan sistem penjualan online atau e-commerce pada Jadebag memiliki fitur untuk sistem penjualan online. Rancangan ini merupakan aplikasi sistem komputerisasi berbasis web dan memuat database pengolahan data informasi secara terpusat sehingga mengolah database tersebut menjadi sebuah informasi yang dibutuhkan oleh para pengguna.

Rancangan sistem penjualan online atau e-commerce pada Jadebag memiliki beberapa kelebihan yaitu:

1) Dengan adanya website e-commerce ini customer dapat membeli produk dengan mudah dan dimana saja secara online dan realtime.

2) Dengan adanya website ini pelanggan yang tidak mempunyai akun instagram dapat melihat dan membeli produk Jade Bag

3) Dengan adanya website ini customer lebih mudah mendapatkan informasi mengenai stok produk secara lengkap dan up to date.

\section{DAFTAR PUSTAKA}

[1] S. Alvin, H. Bagus, and M. Janson, Aplikasi ECommerce Dengan Fitur Top Product Menggunakan Metode Perceptron ( Studi Kasus Toko Kamera ), "Jurnal Ilmu Komputer dan Sistem Informasi", 2018, pp. 210-213.

[2] A. Ita, S. Ety, and N. Andi, Penerapan Business Model Canvas ( BMC ) Untuk Mendorong Mindset Kewirausahaan di Kalangan Mahasiswa, "Jurnal Ketahanan Pangan", 2015, pp. 66-75.

[3] B. A. Habsy, Seni Memehami Penelitian Kuliatatif Dalam Bimbingan Dan Konseling: Studi Literatur, "JURKAM Jurnal Konseling Andi Matappa", vol. 1, 2017, pp. 90-100.

[4] S. Handayani, Perancangan Sistem Informasi Penjualan Berbasis E-Commerce Studi Kasus Toko Kun Jakarta, "ILKOM Jurnal Ilmiah", vol. 10, 2018, pp. 182-189.

[5] D. Anggoro and R. A. Budi Praptono, Pengembangan Model Bisnis Sandiwara Store Dengan Menggunakan Pendekatan Business Model Canvas, "Jurnal e-Proceeding Of Engineering", vol. 3, no. 2, 2016, pp. 3058-3065.

[6] N. A. Sholihah, Analisis Perancangan Model Bisnis dengan Pendekatan Business Model Canvas ( Studi Pada Usaha Kecil Menengah UD. Duta Merpati ), "Jurnal Administrasi Bisnis (JAB)", vol. 61, no. 4, 2018, pp. 183-191.

[7] H. F. S. Gellysa Urva, Pemodelan UML EMarketing Minyak Goreng, "Jurnal Teknologi dan Sistem Informasi", vol.1, no. 2, 2015, pp. 92-101.

[8] D. F. Ariefni and M. B. Legowo, Penerapan Konsep Monitoring Dan Evaluasi Dalam Sistem Informasi Kegiatan Mahasiswa Di Perbanas Institute Jakarta, "Jurnal Teknik Informatika dan Sistem Informasi", vol. 4, 2018, pp. 422-432. 